Andini, Y. D., Muchlas, \& Jumintono. (2018). Online learning model development using google classroom on the topic of administration server. Journal of Vocational Education Studies, 1(2), 6570. DOI: https://doi.org/10.12928/joves.v1i2.698.

\title{
Online learning model development using google classroom on the topic of administration server
}

\author{
Yunita Dwi Andini' ${ }^{1}$, Muchlas'2 ${ }^{2}$ Jumintono² \\ 1SMK Muhammadiyah Mungkid, Jl. Pemandian Blabak, Gatak, Mungkid, Magelang 56512 Indonesia \\ 2Universitas Ahmad Dahlan, Jl. Pramuka 42, Sidikan, Yogyakarta, Indonesia \\ *Corresponding author, e-mail: yunitadwiand@smkmuhmungkid.sch.id
}

\begin{abstract}
This study aims to: (1) generate e-learning-based practice learning model of Server Administration which is valid, useful, exciting, and can be applied to improve the learning outcomes of students in the subject of Administration Server; (2) determine the effectiveness of the implementation of Google Classroom on practice learning Administration Server; (3) monitor the learners in the learning process Server Administration practices inside and outside learning. This study is a Research and Development (R \& D) to the conceptual model and using research procedures Borg and Gall. Results obtained eligibility percentage of media experts of $77.5 \%$ and $78.5 \%$ matter experts with criteria are eligible. Implementation level learning model captured very well at $91.66 \%$. The level of attractiveness of the learners XII TKJ 1 amounted to $83.9 \%$ and XII TKJ 2 of $85.1 \%$ with very interesting criteria. The results of the analysis of the primary field trials assessing the effectiveness aspect, the value of the students after using the learning model and the overall increase learners or $100 \%$ to reach KKM with a limit value of 75 , so it can be said to be a beneficial learning model to increase the number of learners.
\end{abstract}

Keywords: Administration server, Google classroom, Learning model.

\begin{abstract}
Abstrak
Penelitian ini bertujuan untuk: (1) menghasilkan model pembelajaran praktik Administrasi Server berbasis e-learning yang valid, bermanfaat, dan mengasyikkan serta dapat diterapkan untuk meningkatkan hasil belajar siswa dalam mata pelajaran Server Administrasi; (2) menentukan efektivitas penerapan Google Classroom pada praktik pembelajaran Server Administrasi; (3) memantau peserta didik dalam proses pembelajaran praktik Administrasi Server di dalam dan di luar pembelajaran. Penelitian ini adalah Penelitian dan Pengembangan (R\&D) dengan model konseptual dan menggunakan prosedur penelitian Borg dan Gall. Hasil yang diperoleh persentase kelayakan ahli media dari 77,5\% dan 78,5\% ahli materi dengan kriteria memenuhi syarat. Model pembelajaran level implementasi ditangkap dengan sangat baik yaitu 91,66\%. Tingkat daya tarik peserta didik XII TKJ 1 sebesar 83,9\% dan XII TKJ 2 sebesar 85,1\% dengan kriteria sangat menarik. Hasil analisis uji coba lapangan primer menilai aspek efektivitas, nilai siswa setelah menggunakan model pembelajaran dan keseluruhan peningkatan peserta didik atau 100\% mencapai KKM dengan nilai batas 75, sehingga dapat dikatakan model pembelajaran yang bermanfaat untuk meningkatkan jumlah peserta didik.
\end{abstract}

Kata Kunci: Google Classroom, Model pembelajaran, Server administrasi.

\section{INTRODUCTION}

Vocational High School (VHS) is one of the formal education that aims to educate learners to work independently or as a skilled job seeker, professional, and highly disciplined by the demands of the working world. In the Law of the Republic of Indonesia Number 20 the Year 2003 on National Education System especially article 15 mentions particular purpose high schools are preparing learners, mainly to work in a specific field of competence as job seekers with their expertise. These objectives can be achieved if supported by a good quality of learning. 
Dimyati \& Mudjiono (2006) stated that the daily activities of students are learning. The learning process determines the quality of teaching received by students. Principal in learning is active learning methods are used. Gredler (2011) emphasizes that environmental influences be dominant in the learning process, studies of education is not just an academic exercise, studies of knowledge is an essential aspect of both the individual and society. Learning is also the basis for the advancement of society in the future. The primary task of the teacher is learners by conditioning the learners to learn actively explore the potential in him to be able to develop the maximum (Joyce \& Weil, 1980).

The learning environment conditions are a beneficial learning process for students in class XII specifically for practical exam preparation. One of the subjects that must be mastered by students in class XII majoring in Computer and Network Engineering is Server Administration. Server Administration practice learning has much material that requires participants to deliver content that conveys and practices it to be more independent and think critically. Problems that often occur, too much learning content made the participants uncontrolled and focused, making the decisions of the students fail. Students not controlled in tasks or input during learning. Students who do not have individual notes when the material presented is not well absorbed by students and very good for learning outcomes. There is needed control by the teacher when practicing or outside of school to find out the ability of students, not only in class but also to help students learn outside of school.

In learning practice students tend to stand out for competition, most of the performance in carrying out their duties is good, but their nature is only temporary. In other conditions learners whose learning goals focus on improving individual performance and skills development, usually, distribute their performance to hard work in learning. The learning objectives of students in the Server Administration practice learning so far have not been well monitored by the teacher, which results in students being less attentive to themselves. Students tend to be passive in collecting assignments given by the teacher. Through Google Classroom the learning conditions of students are expected to be monitored continuously, and students are required to fulfill their duties in learning actively (Iftakhar, 2016). Google classroom is one of e-learning that describes classes in cyberspace. Monitoring inside or outside of learning by Google classroom can be done online, besides students can also get announcements, materials, assignments, quizzes, value information and online discussion facilities (Izenstark \& Leahy, 2015). Through Google classroom, students are expected to pay more attention to learning goals and can improve student learning outcomes in Server Administration subjects.

\section{RESEARCH METHOD}

The method used in this research is the research and development (Borg \& Gall, 1983). The model used in this research is the development of conceptual models (Johnson \& Henderson, 2002). Analytically, conceptual models that provide components of the product that will develop and the linkages between segments. The theoretical model is closely related to the concept will be implemented and provide an overview of interaction that will be examined to assess systematically empirical fact.

Online learning model development procedure is carried out in several stages, the test of the experts (expert judgment), field testing is limited, and the primary field test. The study would require the development of a series of tests on the learning model. That was done to test the validity of the learning model, whether actually can be beneficial for improving the quality of learning or not. Test phase by experts aims to obtain online learning model validation designed by the practice of learning server administration, including supporting devices.

Andini, Y. D., Muchlas, \& Jumintono. (2018). Online learning model development using google classroom on the topic of administration server. Journal of Vocational Education Studies, 1(2), 6570. DOI: https://doi.org/10.12928/joves.v1i2.698. 
Data analysis techniques aim to process data collected from interviews and questionnaires. The data analysis divided into two types, namely the analysis of qualitative data and quantitative data analysis. Limited field tests and the main squares are used to determine the valid aspects, excellent and exciting. Test the validity obtained from the validation experts, the enforceability of the test derived from a limited field of subject teachers' administration server, test the attractiveness of the finite field was obtained from 6 learners XII TKJ 1 and 6 learners XII TKJ 2. As for the aspect of effectiveness is derived from the primary field test of pretest and posttest.

Data analysis techniques aim to process data collected from interviews and questionnaires. The data analysis divided into two types, namely the analysis of qualitative data and quantitative data analysis. Qualitative data analysis used in the study of this development is only a presentation of qualitative data from experts and respondents in field trials. Sources of qualitative data derived from interviews directly with the informant and written responses to a questionnaire filled simultaneously. Qualitative data also used as a guideline for the revision of the learning model apart from assessment questionnaire development. Quantitative data analysis Quantitative data analysis in the form of questionnaires from media experts, subject matter experts, students, and teachers from questionnaire responses from media experts, subject matter experts, students, and teachers.

The eligibility criteria of this learning model from analysis of the validation test of media and materials. The rules used to assess the development of the learning model with very decent results, decent, reasonably feasible or not feasible. The criteria implementation learning model derived from the questionnaire results with the criteria teachers, excellent, good, fair, less and did not happen. Standards for the attractiveness of this model obtained from the questionnaire results with the requirements of learners is very interesting, exciting, entertaining and uninteresting. By calculating the quantitative data analysis in the form of data from the questionnaire response or media experts, subject matter experts, learners, and teachers. The normality test is done to find out the data from each sample group normal distribution or not.

Parametric test provisions relating to the value of correlation (r) and significance level. Correlation ( $\mathrm{r}$ ) is the relationship between members of the pair and sig. is a significant level, to the rule is if sig. $>0.05$, there is no relationship before and after applying the model and if sig. $<0.05$ then there is a relationship before and after applied to the model. Rules for paired sample t-test test before and after using the model is if sig. $<0.05$ then there is a significant difference, if sig $<0.01$ then there is a very significant difference, whereas if sig> 0.05 , otherwise there is no difference.

Test completeness and learning outcomes were conducted to determine the level of mastery of learning outcomes and learning outcome after the pretest and posttest. Exhaustiveness obtained when learners are equal to or exceed the KKM on the subjects of Administration Server and the learning outcomes achieved from the percentage increase learning outcomes of students.

\section{RESULTS AND DISCUSSION}

\section{Models and Tools Product Support}

This research has produced an online learning model for the practice of the Server Administration in SMK Muhammadiyah Mungkid to use google classroom collaboration and supporting devices. Product model of online learning to use google classroom to practice Administration Server is 1) a description of the learning model (Module 1), class

Andini, Y. D., Muchlas, \& Jumintono. (2018). Online learning model development using google classroom on the topic of administration server. Journal of Vocational Education Studies, 1(2), 6570. DOI: https://doi.org/10.12928/joves.v1i2.698. 
Administration Server, the unit of learning events practice (Module 2), job sheet practice teaching Administration Server (Module 3), guide practice learning online teachers (Module 4), and online practice learning guide for students (Module 5).

\section{Effect of learning models}

Component or aspect of validity last used by the experts in determining the feasibility study model in this study is the overall model of learning. Data consensus of experts from the global aspects of the learning model presented in graphical form in Figure 1.

\section{Expert Validation Results Analysis}

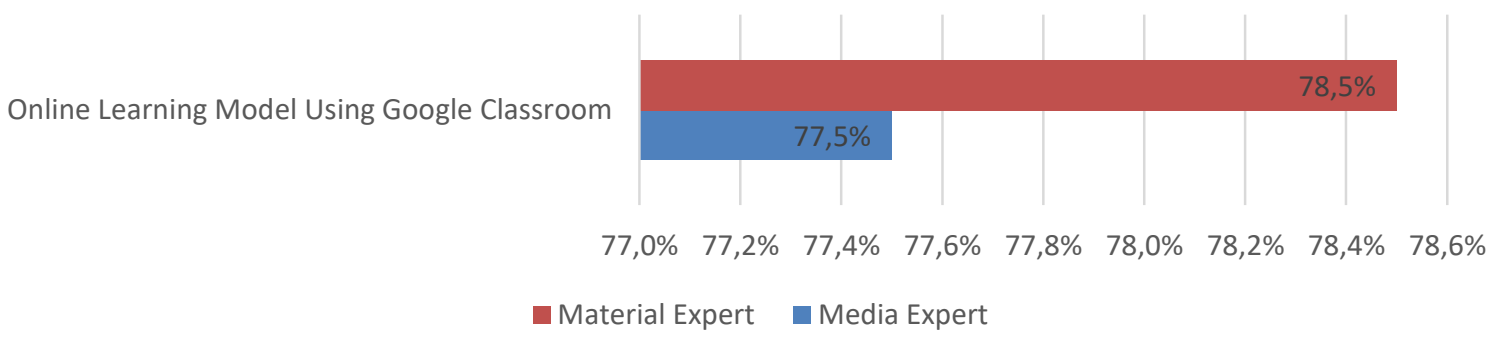

Figure 1. Consensus Experts Learning Model of Aspects Of Overall Model

The feasibility of an online learning media obtained a score of $77.5 \%$, based on the eligibility criteria a score of $77.5 \%$ media declared valid and that means online learning models using Google Classroom fit for use. The feasibility of online learning materials obtained a score of $78.5 \%$, based on the eligibility criteria a score of $78.5 \%$ media declared valid and substance means Administration Server that will apply also collaborated with the online learning model using Google Classroom fit for use.

Components or aspects of the analysis of field trials are used to determine the level of adherence to the attractiveness of the teaching model in this study. The data field trials overall consensus learning model presented in graphical form in Figure 2.

\section{overall field test}

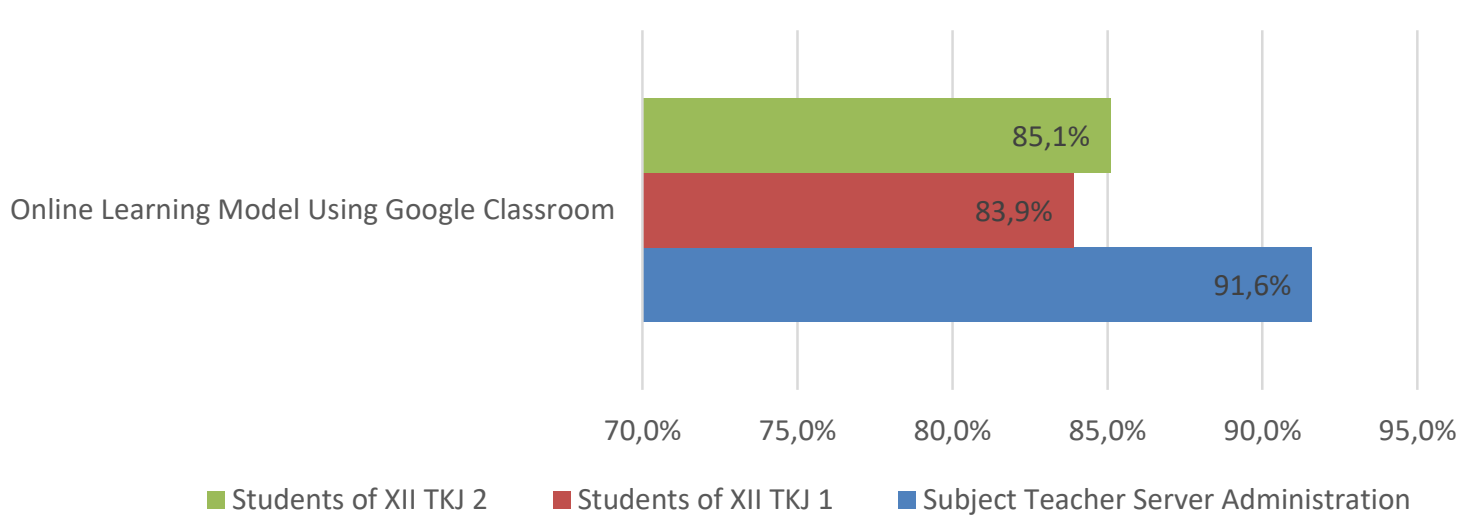

Figure 2. Field Trial Consensus Overall Learning Model

Andini, Y. D., Muchlas, \& Jumintono. (2018). Online learning model development using google classroom on the topic of administration server. Journal of Vocational Education Studies, 1(2), 6570. DOI: https://doi.org/10.12928/joves.v1i2.698. 
The results of the analysis of the early field trials, class XII TKJ 1 has obtained a score of $83.9 \%$ and class XII TKJ 2 has got a score of $85.1 \%$, meaning that the attractiveness of the acquired level is very attractive. Based on the responses of teachers earned a score of 22 with a percentage of $91.66 \%$ with an outstanding degree of enforceability. Aspects of the attractiveness of the teaching model widely supported by Google Classroom display and feature that support that scored high on the attractiveness of the element of the learning model ease of use.

Completeness analysis seen from the average pretest and posttest scores have completed. The results obtained are the following pretest data: the number of pretest (Q1) XII TKJ 1 is in 2229 with an average of 74.3 and the total score of the pretest (Q1) XII TKJ 2 is in 2059 with an average of 73.5 while the subject The KKM server administration is 75 . In the initial stage test (pretest) it can be stated as the value of students under the KKM or incomplete criteria. After using the online learning model using Google Classroom (X) amount of overall scores on tests of the final stage (posttest) is (Q2) XII TKJ 1 was in 2435 with an average of 81.2 while (Q2) XII TKJ 2 is 2319 and the average 82.8. Thus the average value of all learners is above the KKM with complete value criteria.

\section{CONCLUSION}

Based on the analysis and discussion in the previous chapter can disable some findings as follows: results obtained the percentage of media expert feasibility of $77.5 \%$ and the percentage of material experts feasibility validation $78.5 \%$ with decent criteria. The results of field trials produce implementation level of $91.66 \%$ with perfect tests used, while the level of attractiveness of the learners XII TKJ 1 amounted to $83.9 \%$ and XII TKJ 2 of $85.1 \%$ with very interesting criteria. The results of the analysis of the primary field trials to assess the effectiveness of aspects of parametric test obtained with the significance value of 0.000 , which means there is a very significant difference before and after using the learning model. Online learning models using Google Classroom on the subjects of Administration Server after a test conducted by media experts, subject teachers and learners Administration Server can be said that this model can use as the monitoring of learners.

The research to be carried out is expected to produce several things, such as: measuring the level of competence of learners, measuring the extent to which the application of competency-based learning, the realization of an integrated learning model between adaptive subjects and productive subjects.

\section{ACKNOWLEDGEMENT}

I thank SMK Muhammadiyah Magelang Mungkid and Universitas Ahmad Dahlan who has supported my article writing.

\section{REFERENCES}

Borg, W. R., \& Gall, M. D. (1983). Educational Research: An Introduction. New York: Longman. Dimyati \& Mudjiono. (2006). Teaching and learning. Jakarta: Rineka Cipta.

Gredler, M. E. (2011). Learning and Instruction: Theory and Applications. Jakarta: Kencana.

Iftakhar, S. (2016). Google Classroom: What Works and How? Education and Social Sciences, 3, 2289-9855.

Izenstark, A., \& Leahy, K. L. (2015). Google Classroom for Librarians: Features and Opportunities. Library Hi Tech News, 9(32), 1-3.

Johnson, J., \& Henderson, A. (2002). Conceptual models: begin by designing what to design. Interactions, 9(1), 25-32.

Andini, Y. D., Muchlas, \& Jumintono. (2018). Online learning model development using google classroom on the topic of administration server. Journal of Vocational Education Studies, 1(2), 6570. DOI: https://doi.org/10.12928/joves.v1i2.698. 
Joyce, B., \& Weil, M. (1980). Models of Teaching (Second Edition). Englewood Cliffs: PrenticeHall, Inc.

Andini, Y. D., Muchlas, \& Jumintono. (2018). Online learning model development using google classroom on the topic of administration server. Journal of Vocational Education Studies, 1(2), 6570. DOI: https://doi.org/10.12928/joves.v1i2.698. 